\& J.Edu.\&Sci. , The first conference on Biology, (September-2007) ه

\title{
Induction of Gene Amplification Contribute to Sulfonamide Resistance in Proteus mirabilis
}

\author{
Zeerak Faque Ahmed AbdulRahman \\ Dept of Biology/ College of Science Education/University of \\ Sallahaddin
}

\begin{abstract}
الخلاصة
تم جمع ثلاثين عزلة من بكتريا Proteus mirabilis من مصادر مرضية مختلفة ( البول و الجروح، الاذن و الجروح ) . جميع العزلات تم تعريضها لسلسلة من التجارب للتأكد بأن جميع ثلك العز لات عائدة الى جنس Proteus mirabilis. و التي تُ التعرف عليها بالاعنماد على الصفات المظهرية و المزرعية و التجارب البايوكيميائية. نم اجراه عملية

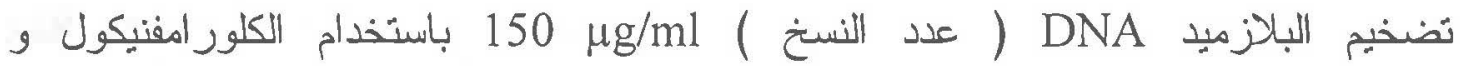
التتر اسايكلين ( العزلات المختارة كانت مقاومة الكلور امفنيكول و التتر اسايكلين لكن حساسة للتز امثبريم ) بصورة منفصلة في طور اللو غاريتمي للعز لات المختارة ). تم ملاحظة التضخيم الحقيقي لثلاث عزلات وهي عزلة رقم 2,8,10 بالنسبة للكلور امفنيكول و عزلة رقم 1 ، 11 Proteus للتتر اسايكلين بين سبعة من تلك العزلات التي تم اختبارها. ان تلقيح بكتريا

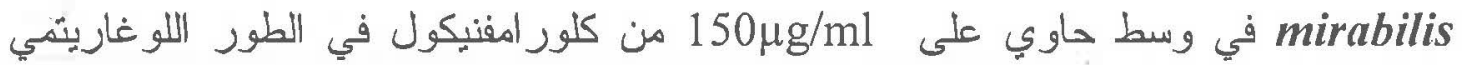
لمدة 20 ساعة ، فان كلور امفنيكول سوف بحفز عملية التضخيم الاختباري ومن ضمنها الجينات المقاومة لل Sulfonamide. هذه النتيجة تبين بأن الـ DNA المضخمة الحاوية على تلك الجينات سوفـ تعطي صفة المقاومة لهذا المضاد الحيوي منّى ماكان الــ DNA منو اجد بكميات كبيرة (بفعل التضخيم) مقارنة مع الـ DNA غير المضخم. هذه الميكانيكية تمثل مستوى جديد من السيطرة على تعبير الجينات في النظام البكثيري و الذي بسمى بثحفيز النضخيم الاخنياري للجين.
\end{abstract}

\section{Abstract}

Thirty Isolates of Proteus mirabilis from different clinical sources (Urine, Burn, Ear, and Wounds) were recovered. All isolates were subjected to the series of confirming tests to insure that these isolates are Proteus mirabilis, which identified selectively by unique feature of morphological, cultural, and biochemical tests. Amplification of plasmid DNA content (Copy Numbers), performed using $150 \mu \mathrm{g} / \mathrm{ml}$

-Presented at the first conference on Biology, University of Mosul, college of Education, 4 - 5 September 2007 
chloramphenicol and tetracycline (The chosen isolates were resistant to chloramphenicol and tetracycline, but sensitive to trimethoprim) separately in the lag phase of the tested bacterial isolates. Among seven tested isolates true amplification perceived in isolate No. 2, 8, and 10 for Chloramphenicol and isolate No. 1 and 11 for tetracycline. When cells of Proteus mirabilis cultured in medium containing chloramphenicol at 150 $\mu \mathrm{g} / \mathrm{ml}$ a growth lag of $20 \mathrm{hrs}$ ensure. During this lag, chloramphenicol induces selective amplification, including the gene for resistance to sulfonamide. This result suggests that amplified DNA contained genes that contributed to sulfonamide resistance when present in greater amount compared with non-amplified DNA. This mechanism represents a new level of control of gene expression in bacterial system- namely, the induction of selective gene amplification.

\section{Introduction}

Proteus mirabilis considered as a member of and large family of Gram-negative bacteria that exhibit a considerable degree of relatedness is the Enterobacteriaceae. They are saprobes in soil, manure, sewage, and polluted water and commensals of human large bowel and other animals. They are commonly involved in urinary tract infection, wound infection, pneumonia, septicemia, and occasionally in infant diarrhea. Proteus urinary infections appear to stimulate renal stones and damage due to the urease. They produce and rise in urine $\mathrm{pH}$. (1.2).

When bacterial cells which harbor certain antibiotic resistance plasmids are cultured in media containing high concentration of the antibiotic to which resistance is conferred, there is often an increase in the copy number of the resistance genes. This increase may be a result of an increase in the copy number of the plasmid or of a selective amplification of only the specific region carrying drug resistance genes in the $\mathrm{R}$ plasmid (3.4.5.6). That is the $\mathrm{R}$ plasmid increase in size owing to repeated tandem duplication of the antibiotic resistance genes. This process requires an active bacterial Rec system, in a controlled way, they can be used to explore the mechanism involved in DNA replication and to analyze the different strategies that DNA replication to other critical event in the cell cycle (7).

This enable bacteria to rapid short-term adaption to change envirommental condition, they confer gene amplification (8). The colicinogenic factor ColE1 in $\boldsymbol{E}$. coli continue to replicate by a semi conservative mechanism in the presence of chloramphenicol for 10-15 hours, long after chromosomal DNA synthesis has terminated. Following chloramphenicol addition the rate of plasmid DNA synthesis gradually increase to an extent dependent on the medium employed, the copy number of ColE1 DNA molecule that accumulate under this condition 
approach about 3000 copies per cell, representing 125 - fold increase over the normal level of 24 copies per cell. The system is particularly convenient for study the mechanism of DNA replication (9).

Amplification of drug resistance genes was detected at low frequency in Proteus mirabilis cell population that had not previously been exposed to antibiotics, suggesting that the subsequent application of a selective regimen for high resistance favored out growth of the sub population containing the amplified gene (10). Therefore, this report try to study the process of amplification and their consequence on the development of the resistance gene to other antibiotic (trimethoprim).

\section{Materials and Methods}

\section{Bacterial Isolates Collection:}

Thirty isolates of Proteus mirabilis were obtained from various sources of human infection (urine, ear, blood, and wound) from Al. Jumhuria, hospital in Erbil city/ Iraq. The cultures were maintained by subculture on nutrient agar slant and incubated for 24 hrs at $37 \mathrm{C}^{\circ}$, then kept in the refrigerator at $4 \mathrm{C}^{\circ}$ until it used.

\section{Antibiotic Resistance Experiment:}

To study the ability of Proteus mirabilis isolates to resist the antibiotics under study (chlormaphenicol, tetracycline, and trimethoprim), nutrient agar was used as growth media, after sterilization and cooling to $50 \mathrm{C}^{\circ}$, a final concentration of antibiotics mentioned were added, the medium were mixed and poured into sterile petridish. These agar plated containing antibiotics will inoculated with Proteus mirabilis isolated by streaking method, then incubated for 24 hours at $37 \mathrm{C}^{\circ}$, the results then recorded (11).

\section{Bacterial DNA Amplification:}

Amplification of the plasmid DNA content in the bacterial isolates was carried out according to the method mentioned by Norgad et $\mathrm{al}^{(12) \text {. }}$ Sterilized nutrient broth samples of $2 \times 55 \mathrm{ml}$ containing $15 \mu \mathrm{g} / \mathrm{ml}$ of choramphenicol, each was inoculated with a single colony of each bacterial isolate, incubated with shaking $(100 \mathrm{rpm})$ at $37 \mathrm{C}^{\circ}$ for several hours until the culture reach mid logarithmic phase (O.D approximately 0.5 at $590 \mathrm{~nm}$ ). The content of plasmid DNA was amplified by adding $150 \mu \mathrm{g} / \mathrm{ml}$ of chloramphenicol to one of $55 \mathrm{ml}$ culture, incubation continued at $(100 \mathrm{rpm})$ for further 8-12 hours. Plasmid DNA extracted according to Birnboim and Doly ${ }^{(13)}$ from the two $55 \mathrm{ml}$ culture (un amplified and amplified) and the concentration of DNA yield was estimated. In addition, the antibiotic tetracycline was used by the same way mentioned above to amplify the plasmid DNA content in the bacterial isolates. 


\section{Isolation of Plasmid DNA Content:}

In order to extract the plasmid DNA, a method described by (13) was followed by centrifugation of the $50 \mathrm{ml}$ of amplified and un amplified culture, for 10 minutes at $8000 \mathrm{rpm}$. The pellet are suspended in $2 \mathrm{ml}$ solutions $\mathrm{I}$, then $100 \mu \mathrm{l}$ as $50 \mathrm{mg} / \mathrm{ml}$ lysozyme was added to the suspension left at room temperature for 10 minutes, after that $4 \mathrm{ml}$ of solution II added, vortexed and left on ice for 10 minutes. Then $2 \mathrm{ml}$ of cold $5 \mathrm{M}$ potassium acetate was added and left on ice for another 10 minutes, after that centrifugation at $8000 \mathrm{rpm}$ to precipitate cell debris and high molecular weight DNA were preformed. In order to remove protein, the supernatant transferred to clean tube equal volume of chloroform isoamylalchol (24:1) added, centrifuged for 10 minutes at $8000 \mathrm{rpm}$, this step repeated several times. The aqueous layer was transferred to another clean tube and its volume estimated, the $1 / 10$ of this volume solution III added with two volume of absolute ethanol to precipitate the nucleic acid, the mixture was left for 30 minutes then centrifugated for 10 minutes at $8000 \mathrm{rpm}$. The pellet washed with $5 \mathrm{ml}$ $70 \%$ ethanol, centrifuged for 10 minutes at $8000 \mathrm{rpm}$, after that the pellet dried, re suspended with $0.5 \mathrm{ml} \mathrm{TE}$ buffer and stored at $-20 \mathrm{C}^{\circ}$.

\section{-Spectrophotometric Quantation of Plasmid DNA:}

A method described by Ahmed ${ }^{(14)}$ was used. A hundred micro liter of prepared plasmid DNA as diluted by TE buffer to $1 \mathrm{ml}$ and the optical density was measured at $260 \mathrm{~nm}$. The concentration of plasmid DNA calculated according to the equation.

Optical density of 1 at $260 \mathrm{~nm}=50 \mu \mathrm{g} / \mathrm{ml}$.

\section{-Detection of Trimethoprim Resistant Isolates:}

After amplification process performed, a serial dilution for the amplified culture isolates were conducted; the last three dilution were spread on to nutrient agar media containing final concentration of trimethoprim, incubated for 24-72 hours at $37 \mathrm{C}^{\circ}$ and the result recorded (15).

\section{Results and Discussion}

\section{Bacterial identification:-}

All bacterial isolates collected from patient were subjected to the series of confirming tests to ensure that these isolated recovered belong to Proteus mirabilis.

Preparation of bacterial smear showed that they are gram negative, straight rod, round end, motile with peritrichous flagella, and non spore former. In addition biochemical tests revealed that all isolates 
were citrate and urease positive. Further more cultural growth characterized by distinctive swarming formation on blood agar (16).

\section{Antibiotic Resistance Patterns:-}

The antibiotic resistance profile of the bacterial isolates were screened for their resistance to chlormaphinicol, Tetracycline, and Trimethoprim, using streaking plate method onto antibiotic media as mentioned in materials and methods.

Results indicate that bacterial isolates revealed resistance to the above antibiotics with the ratio $69.5 \%, 52.5 \%$, and $33.4 \%$ for $\mathrm{Cm}$, tet, and $\mathrm{Tm}$ respectively. The high resistance of the bacterial isolates in this study to different antibiotics may be related to the presence and dissemination of plasmid within heterogenous population of these bacteria (17).

\section{Induction of Amplification Process in The Bacterial Isolates:}

The number of different bacterial isolates that are resistant to final concentration of chloramphenicol and tetracycline were chosen. Then these resistant isolates tested for their amplification. Results showed that only three isolated for $\mathrm{Cm}$ and two isolates for Tc show no remarkable change in their growth optical density at $590 \mathrm{~nm}$ after adding 10 fold concentration $(15 \mu \mathrm{g} / \mathrm{ml})$ of $\mathrm{Cm}$ and Tc separately in the log phase and further incubated for 12 hours at $37 \mathrm{C}^{\circ}$.

Table (1): Amplification of Plasmid DNA content in chosen bacterial isolate

\begin{tabular}{|c|c|c|c|c|c|}
\hline $\begin{array}{c}\text { Isolate } \\
\text { No. }\end{array}$ & $\begin{array}{c}\text { O.D.at } 600 \\
\text { nm before } \\
\text { adding of } \\
\text { tetracycline }\end{array}$ & $\begin{array}{c}\mu \mathrm{g} / \mathrm{ml} \\
\text { plasmid } \\
\text { DNA }\end{array}$ & $\begin{array}{c}\text { O.D. at } \\
600 \mathrm{~nm} \\
\text { after } \\
\text { addition } \\
\text { of Cm }\end{array}$ & $\begin{array}{c}\mu \mathrm{g} / \mathrm{ml} \\
\text { plasmid } \\
\text { DNA }\end{array}$ & $\begin{array}{c}\text { Fold of } \\
\text { Amplification }\end{array}$ \\
\hline 1 & 0.612 & 22.0 & 0.700 & 213.0 & 9.6 \\
\hline 6 & 0.475 & 39.5 & 0.995 & 115.0 & 2.9 \\
\hline 11 & 0.426 & 45.0 & 0.463 & 100.0 & 2.2 \\
\hline 20 & 0.525 & 42.5 & 1.050 & 123.5 & 2.8 \\
\hline 23 & 0.300 & 21.5 & 0.856 & 98.5 & 4.5 \\
\hline 26 & 0.441 & 52.5 & 1.200 & 102.3 & 1.9 \\
\hline 30 & 0.336 & 33.5 & 0.985 & 242.0 & 7.2 \\
\hline
\end{tabular}


Table (2): Amplification of Plasmid DNA content in chosen bacterial isolates

\begin{tabular}{|c|c|c|c|c|c|}
\hline $\begin{array}{c}\text { Isolate } \\
\text { No. }\end{array}$ & $\begin{array}{c}\text { O.D. 600 } \\
\text { before } \\
\text { addition } \\
\text { of } \\
\text { chloram. }\end{array}$ & $\begin{array}{c}\mu \mathrm{g} / \mathrm{ml} \\
\text { plasmid } \\
\text { DNA }\end{array}$ & $\begin{array}{c}\text { O.D. 600 } \\
\text { after } \\
\text { addition } \\
\text { of } \\
\text { chloram }\end{array}$ & $\begin{array}{c}\mu \mathrm{g} / \mathrm{ml} \\
\text { plasmid } \\
\text { DNA }\end{array}$ & $\begin{array}{c}\text { Fold of } \\
\text { Amplification }\end{array}$ \\
\hline 2 & 0.550 & 47.0 & 0.600 & 240.0 & 5.1 \\
\hline 7 & 0.400 & 65.5 & 1.000 & 377.0 & 5.7 \\
\hline 8 & 0.539 & 59.4 & 0.540 & 455.0 & 7.6 \\
\hline 9 & 0.670 & 13.0 & 1.110 & 426.5 & 32.8 \\
\hline 10 & 0.406 & 79.0 & 0.457 & 414.0 & 5.2 \\
\hline 16 & 0.430 & 66.7 & 0.978 & 320.0 & 4.7 \\
\hline 22 & 0.410 & 80.0 & 1.095 & 221.5 & 2.7 \\
\hline
\end{tabular}

From table (1) and (2) we can conclude that three isolated (2,8, and 10) have the ability to amplify their plasmid copy number in the presence of $15 \mu \mathrm{g} / \mathrm{ml}$ chloramphenicol; two isolates $(1$, and 11$)$ have ability to amplify their plasmid copy number in the presence of $15 \mu \mathrm{g} / \mathrm{ml}$ tetracycline. There is a slight increase in the optical density reading at $590 \mathrm{~nm}$ of the growth bacterial cultures before and after addition of $150 \mu \mathrm{g} / \mathrm{ml}$ chloramphenicol and tetracycline separately which indicate that there is no remarkable increase in total count of bacterial cells. On the other hand there are a remarkable increase in the yield of plasmid DNA, which might considered as real amplification. The yield of DNA show a notable increase in the isolate 2,8, and 10 comparing with that before addition of

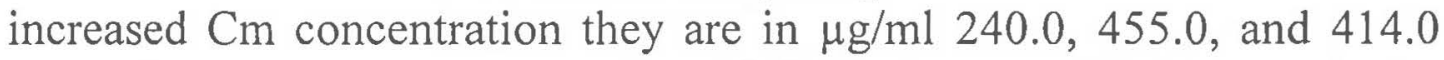
respectively while the yield of plasmid DNA show notable increase in the isolate 1, and 11 comparing with those before addition of tetracycline, they are 213.0 , and $100 \mu \mathrm{g} / \mathrm{ml}$ respectively. The folds of increase in the plasmid DNA yield occur in range 5.1-7.2 with chlormaphenicol while the range was between 2.2-9.6 with tetracycline. These Plasmid DNA in those isolates (show real amplification) can be used as cloning vectors in the genetic engineering technique.

The action of chloramphenicol or tetracycline on amplification of DNA content seems to be related with cell cycle, because protein that required for the cell division are made in early stage for above process (18). Addition of $\mathrm{Cm}$ and $\mathrm{Tc}$ will inhibit the synthesis of new protein comparing host encoded DNA polymerase I ( $\mathrm{Pol} \mathrm{I}$ ) protein and plasmid encoded (Rop) protein. 
Pol I is exist in excess amount, so even in the absence of protein synthesis there is enough Pol I in the bacterial cells for may rounds of plasmid replication. Oppositely, Rop is limiting, so in the complete absence of protein synthesis process there is insufficient Rop to inhibit replication and accumulation of plasmid to a copy number much greater than normally found (10).

More over blocking chromosomal replication by addition of chloramphenicol will put all protein including DNA polymerase to serve for plasmid replication. Worth mentioned it has been found that the degree of amplification can be controlled by manipulation of the concentration of chloramphenicol in the growth medium (20).

On the other hand the failure of the other isolates to amplify it is copy number may be due to over production of initior protein, which can reduce of inhibit plasmid replication (21), because the cell division was continuous and the O.D altered from 0.400 to 1.000 and from 0.670 to 1.110 and from 0.430 to 0.970 and from 0.410 to 1.095 respectively for chlormaphenicol.

Our results are in accordance with (22) who found that Proteus mirabilis strain containing an $\mathrm{R}$. plasmid in the presence of chloramphenicol, amplification of plasmid borne, determinant occurred.

\section{Selections of Trimethoprim Resistance Isolates:}

Trimethoprim resistant mutant was isolated essentially as describe by Nichalas and Guay ${ }^{(15)}$.

After the growth of resistant mutant, the level of trimethoprim resistance for each mutant was estimated by observing the heavy growth of this mutant on media provided by final concentration for this antibiotic in order to confirm the stability of this characteristic (trimethoprim resistance) compared with un amplified isolates as shown in Fig (1).

The selective increase in trimethoprim resistance could result from a mutation in the resistance gene or its promotor or from selective amplification of DNA carrying trimethoprim resistance determinant (23).

Another mechanism suggests that amplified DNA contained a gene designated sur that contributed to trimethoprim resistance when present in greater amount by action of amplification process compared with those which um amplified (15).

Our results are in agreement with that reported by (23) who found that the growth of $\boldsymbol{E}$. coli in medium containing high concentration of neomycin resulted in cells which were highly resistant to kanomycin and neomycin simultaneously.

The data presented in this paper suggest a new level of control for gene expression-namely, the specific induction of the amplification of single gene or gene product of the amplified DNA segment. These 


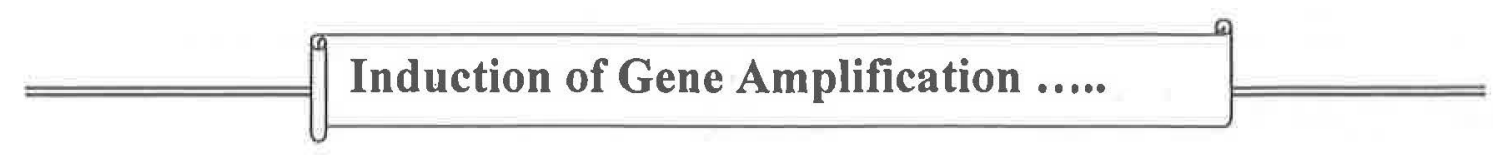

selective amplification seen in drug resistance plasmid can provide the decisive selective advantage that allow the host cell to survive.

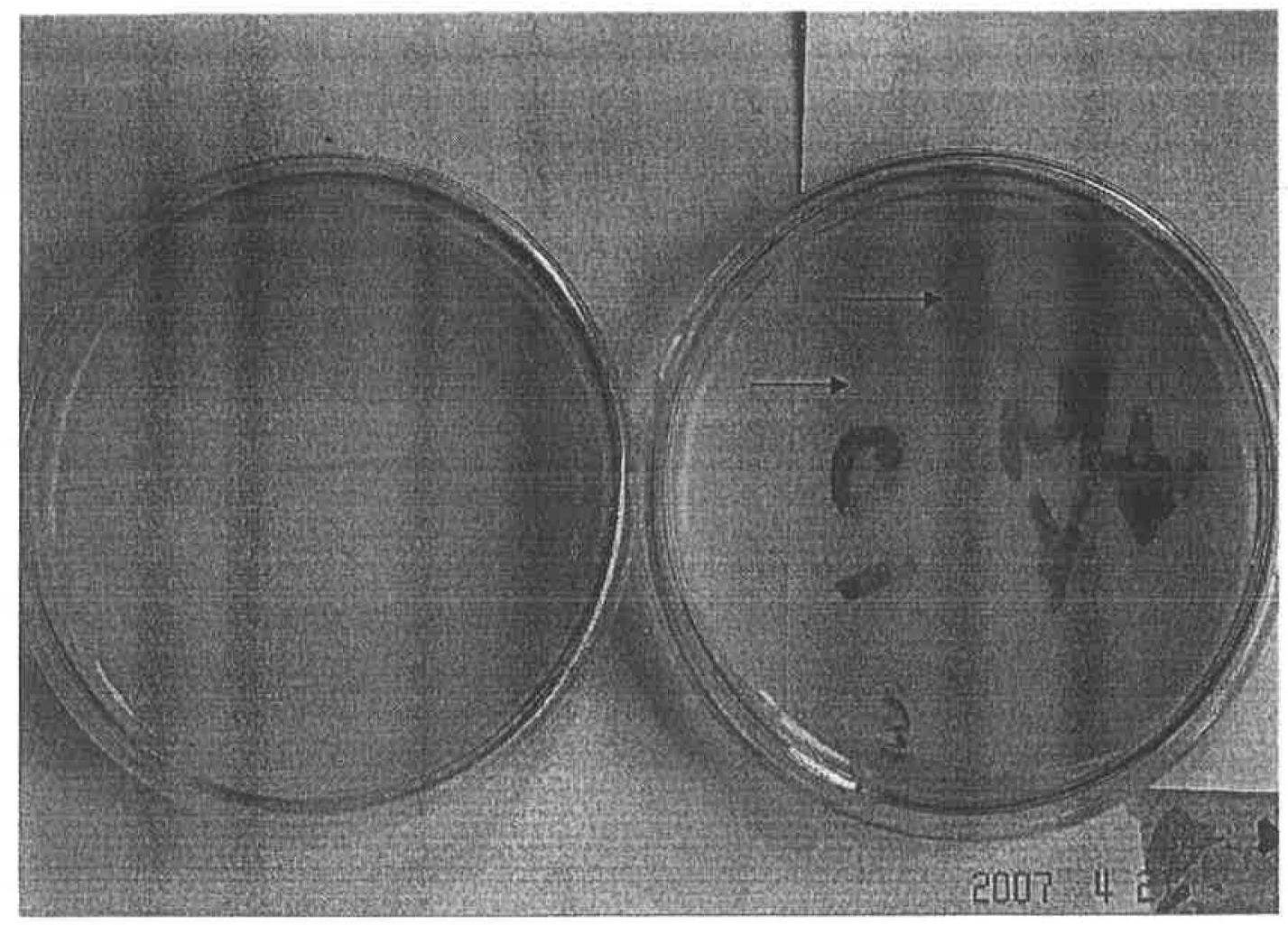

Fig. (1): Development of resistance to trimethoprim after amplification. A- Before amplification.

B- After amplification. 


\section{References:-}

1. Jawetz, E.; Melnick, J. L. and E.A. Adelberg. Medical Microbiology. $20^{\text {th }}$ edition. Prentice Hall, Appletons and Lange. (1995).

2. Talaro, K. P. and Talaro, A. Foundation in Microbiology. $4^{\text {th }}$ edition. McGrow-Hill companies, Inc. (2002).

3. Chandler, M; tour, E. B.; Willems, D. and Caro, LSome. Mol. Gen.Genet. 176:221-231. . (1979).

4. Mattes, R.; Iida, S. and Schmitt, R. .Mol. Gen.Genet. 168:173184.( 1979).

5. Meyer, J. and Iida, S. Mol.Gen.Genet. 176:209-219. (1979).

6. Wiebauer, K.; Schraml, S. Shales, S. W. and Schmitt, R.. J. Bacterial. 147:851-859. (1981).

7. Zund, P. and Lebek, G. Plasmid. 3:65-69. (1980).

8. Cheah, U. E.; Weigand, W. A. and Stark, B. C.. plasmid. 18:127134. (1987).

9. Clewell, D. B. J. Bacteriol., 110:667-676. (1972)

10.Hashimoto, H., and Rowand, R.J. Bacteriol.,123:56-68. 1975)

11.Grant, A., and Pittard, J. J.Bacteriol., 120:185-188. (1974).

12.Norgard,M; Emighoz, K. and Monahan, J. J. Bacteriol., 138:270277. (1979).

13.Birnboim, H.C. and Doly, J. -Nucleic acid Res. 7:1513-1524. (1979).

14.Ahmed, K. D. Ph.D. thesis. Univ. of Durhan. England. (1989).

15.Nicholas, B.P. and Guay, G.G. Antimicrob. Agant and chemotherapy. 33(12):2042-2048. (1989).

16.Lennete, E.; Balows, A.; Hansler, W. and shadomy, H. Manual of clinical Microbiology. $4^{\text {th }}$ ed., American society for Microbiology, Washington DC. (1985).

17.Levy, S.; Hedges, R.; Sullivan, F. and Medeiros, H. J.Antimicrob. chemother., 76:7-16. (1985).

18.Kruse, U. and Stahl, Microbiol., Rev., 53:491-516. . (1989).

19.Datta, N. and Huges, V., 306:616-617. (1983).

20.Young, C.; Becnhfor, D.H. and Figurck, D.H. 130:1613-1621. (1989).

21.Thomas, C. M. Plasmid. 16:15-29. (1986).

22.Perlaman D. and Rowand, R.H. Journal of Bacteriology. 123:1013-1034. (1975).

23.Peterson, B.C. and Rowand, J. Bacteriol., 164(3):1359-1361. .(1985). 